THURSDAY，JULY II， I 878

\section{SCIENCE IN SCHOOLS}

$\mathrm{W}^{\mathrm{n}}$ $\mathrm{E}$ print with pleasure on another page a remarkable article from the Times of Monday. In itself the article may present nothing remarkable to the readers of NATURE, but as the deliberate utterance of the leading organ of opinion in this country, it marks a distinct stage of progress towards a more enlightened conception of what constitutes education. We hope that it is significant of the near approach of a radical change of the conception in this country of what subjects should be included in elementary education. We need not be surprised at the fate of Sir John Lubbock's Bill for the introduction of elementary science into schools, when such erroneous conceptions of what science is apparently exist in the mind of the Minister of Education in the House of Commons, Lord George Hamilton. The Vice-President of the Council has much to learn, when his idea of the Royal Society, one of the most venerable institutions in the country, is that of a kind of select Polytechnic, where "lectures" are delivered on "biology, chemistry, natural history, mechanics, astronomy, mathematics, and botany." But he is new to his work, and we must hope that the debate of Thursday last may lead him to obtain a more accurate conception of what is meant by elementary science.

I)r. Lyon Playfair, we believe, pointed out what is one of the great hindrances to the introduction of science into elcmentary schools ; the mere name, "sciencc," frightens ministers, inspectors, school-boards, and teachers; perhaps if the simpler phrase, "elementary knowledge," were used, the simple-minded individuals in whose hands are the training of our future citizens might find that they themselves had been compelled to become acquainted with it to their cost after they left school, and that it would have been much better for them had they had some little training in it before entering into the thick of the fight.

The most notable feature in the Times article, as well as in Thursday's debate, is the fact that it has at last dawned upon the leaders of opinion and the makers of our laws, that "education" and "instruction" are different things, and that a man may learn a great many "facts" at school, and have his education to begin when he leaves it. It is lamentable that we have to be continually reminded that we are the only one of the great European countries where this distinction is not recognised and practically carried out in education. Our whole system of education, hitherto, has been a mere cramming of the children's memories with words, words, words, to the weariness of children and teachers, and with results unsatisfactory to all concerned. As the Times puts it:- "To be taught something about gravitation, about atmospheric pressure, about the effects of temperature, and other simple matters of like kind, which would admit "of experimental illustration, and which would call upon the learner to make statements in his own words instead of in those of somebody else, would be so many steps towards real mental development." Sir John Lubbock gave a most conclusive refutation of the Vot. xvirr.-No. 454 idca that the teaching of science must be attended with hitherto unexperienced difficulties, and at the same time proved what a relief science-teaching would be to the ordinary clull routine of instruction, when he told the House that in the Scotch schools the authorities began to take alarm because science-teaching was found so comparatively casy and pleasant by the children. As to the argument that children who bave been taught to know something about the objects and forces with which they every day come into contact contract a clistaste for manual labour, we should have thought it had been long ago played out; it has almost as much force as the story told by another speaker of the boy who had been impudent to his master because the latter could not read his newspaper.

It is unnecessary for ths to go again into the merits of the question which has been so often and so thoroughly discussed in these pages, especially as the Times has put it quite as forcibly as there is occasion for doing at present. It certainly seems sad, nationally suicidal, indeed, that a few more millions of those who will have the destinies of this country in their hands, are likely to be launched into active life, with all their education to acquire, ere legislation steps in to give us the advantages which nearly every other civilised nation gives to its children. Every day we hear of the ignorance of the working classes, every other month "congresses" are held to devise means to remedy the consequences of this ignorance-ignorance of the laws of health, ignorance of houschold economy, ignorance of the implements and objccts of labour, ignorance of the laws of labour and production, ignorance of the nature of the commonest objects with which they come into contact every day, ignorance of almost everything which it would be useful and nationally beneficial for them to know-an ignorance, alas! more or less shared by the "curled darlings" of the nation. Yet while every day's paper shows how keen is the industrial competition with other nations, and how in one department after another we are being outstripped by the results of better-i.e., more scientific-knowledge, the poor pittance of "elementary knowledge" asked for in Sir John Lubbock's Bill is refused by a minister whose own "education" leaves much to be desired. This state of things cannot long contimue, and with such advocates for the children as the Times and Mr. Forster, we may hope that next time Sir John Lubbock brings forward his Bill it will meet with a happier fate.

\section{THE FUBILEE OF UNIVERSITY COLLEGE}

I ORD GRANVILLE'S admirably reasoned and L temperate speech at the jubilee of University College on 'Tuesday, reminds us how things move in this country. It records balf a dozen great advances which are now accepted cordially and universally, with all of which University College is more or less identified, and in promoting which it has never failed to take a leading part.

To begin with, there is the absolute catholicity of its offer to the student-the invitation on its motto is Cuncti adsint, meriteque expectent pramia palma. When the University 
of London began in 1828 , and when University College was incorporated in 1836 , Oxford and Cambridge had not dreamt of throwing open their doors to dissenters. Today the whole world so absolutely recognises the propriety of the step which University College then took, that it is difficult to give it enough credit for a courage which was then without precedent in England. Only the other day its invitation has been widened still farther. Cuncti adsint is to be understood as including Cuncte adsint, and women as well as men will henceforth have unrestricted access to the classes in the faculties of arts, law, and science. Women are at least as much influenced in character by the kind of education which is given them as men are, and the action of University College guarantees that women-in London, at least-will have at their disposal the best education which England can offer.

The Chancellor of the University of London reminded us that the new demands of teachers of science have compelled institutions like University College to extend their buildings and to provide laboratory facilities in addition to the class-rooms and lectures of old days. University College is not alone in recognising this vital fact. King's College has thorougbly developed its practical teaching; the Scotch Universities have latterly been vry much alive on the subject; Owens College, as becomes a new institution claiming to take rank with the most advanced teaching bodies of the day, has given exceptional prominence to laboratory work. But University College has not been unconscious of the movement, and she purposes, if possible, to outstrip her rivals.

The last movement, in which Lord Granville reminds us that her action has counted for a great deal, is that to extend the English definition of a university. She considers herself entitled to that appellation. "Now the term ' University,' " says Lord Granville, "has been differently understood by different persons and by different nations, and I think that the exact construction of it is rery likely to be still more minutely debated in consequence of the able efforts of one of the most distinguished sturlents of your college, now the most successful president of Owens College, whom we sec among us, who has raised the question whether the number of universities ought not to be increased. In France 'university' means an aggregrate of all the schools and colleges of the kingdom. In Germany their famous universities are really professorial schools. Our two elder universities are really academical institutions-an aggregate of colleges. You know that the London University is not a teaching body at all, and that it is only an examining body, depending upon other sources, of which this college is the most prolific in giving us candidates for our cxaminations." The institution of University College has done much, the movement of Owens College has done more, to widen our ideas of what a University might do. There is no reason why we should be confined to the cxisting type of "academical institutions-an aggregate of colleges," supplemented by an examining body depending on other sources. We do not aim at French centralisation, but there is no reason why one or two universities on the German or the Scotch model should not be added to the very limited list of our English
Universities. An amalgamation of University College and King's College into a teaching University of London would be a natural consequence of such a movement.

\section{WINDMILLS AND WATERFALLS}

O $U R$ readers may remember the consternation caused some years ago by the publication of Prof. Jevons's work on our coal supplies, and the alarmed inference drawn from his calculations that the days of Britain's supremacy and prosperity were numbered. Certainly, if our prosperity is entirely dependent on our coal supplies, there can be no doubt that ere very long the beginning of the end will have arrived. Abundant as our coal supplies are their consumption at the rate of about 150 million tons annually cannot go on for ever; and while we may have the ships and the money too, it would be a serious thing for England if she had to look abroad for her greatest source of physical power. It is certainly at present difficult to see how the work of the world could be carried on if the supply of coal were completely exhausted; still if man were compelled to find a substitute or relapse into savagery or even perish altogether, we think the chances are he would be able in some way, without detriment to his progress, to adapt himself to his new circumstances. These ideas have been suggested by an interesting lecture, just published, recently delivered at Glasgow by Dr. C. W. Siemens, "On the Utilisation of Heat and other Natural Forces."

"The supremacy," he justly says, "which man enjoys over the animate and inanimate creation, and for which Divine Authority may be quoted, cannot be said to be the result of his superior muscular development, for amongst the members of the animal kingdom there are many which are his superiors in strength, agility, swiftness, and in natural aptitude to provide themselves against the vicissitudes of cold and hunger. The compensating advantage in our favour is the intelligence with which we are enabled to call forces of nature not our own into requisition to do our behests. It would not be too much to say that the power of man consists really in his ability to direct the forces of nature, and that the degree of civilisation to which he has attained is commensurate with his command of those forces."

Could any more forcible argument be urged in favour of the national advantages of scientific research, or of the yearly increasing importance of scientific knowledge in the every-day life of humanity?

Fortunately Dr. Siemens, in his lecture, gives us a pretty wide glimpse of hope that we need not despair because of the prospective exhaustion of the existing means of producing utilisable heat. Other methods, he suggests, might be found of bringing into action this greatest source of mechanical power, and that even now one of these methods might be so used that the exhaustion of our coal might be postponed for a considerably longer period than has been calculated. Dr. Siemens traces the progress of our knowledge of the real nature of heat and of the methods of ascertaining its mechanical equivalent. He shows how gradually we have learned to produce a greater and greater amount of mechanical effect from the 